science. Cordus, for instance, is not named, whose 'Dispensatorium,' published in 1598, contains a complete list of the adulterations of drugs and some articles of diet (such as sugar), with practical directions for detecting them by their physical properties. During the French revolutionary period, the dreadful mania for commercial swindling, so graphically described by $M$. Goncourt,* gave an unexampled activity to every kind of fraudulent sophistication. The consequence, not the cause, was the translation of Remer's work by Bouillon Lagrange, in 1816, and the appearance of many more French writers, of whom a list is given in the preface to the 'Dictionnaire.' The most valuable previous to the work under review, seems to be the "Traité des Moyens de Reconnaître les Falsifications des Drogues simples et composées,' by MM. Bussy and Bourtron-Charlard.

So that even if he did not come into MS. knowledge by inheritance, any manufacturer who could get a foreign book translated for him, need never have been at a loss to know what articles to use for adulteration, and what his customers are likely to find out. The advantage of the modern works over the older is, that while the latter simply enumerate the methods of fraud, and give a customer data by which he may detect it, the former put him in possession of accurate means of ascertaining not only the presence, but the amount also, of the enemy -an important consideration in distinguishing the real guilty adulterations from the innocent. Instead therefore of being frightened at the recent multiplication of that literature, of which there are quoted in the heading two of the most commonly known examples, we cannot but consider it a safeguard of continually increasing value. M. Chevallier's volumes have been translated into German, with valuable additions by Dr. Westrumb at Göttingen, and it is probable that an English version would be well received both in this country and in America, especially if it were brought up quite to the scientific knowledge of the present time.

\title{
REVIEW VI.
}

1. History of Medicine from its Origin to the Nineteenth Century; with an Appendix, containing a Philosophical and Historical Review of Medicine to the Present Time. By P. V. Revouand, M.D. Translated fiom the French by Connelius G. Comegrs, M.D., Professor of the Institutes of Medicine, Miami Medical College.-Cincinnati, 1856. 8vo, pp. 719.

2. The Medical Profession in Ancient Times: an Anniversary Discourse delivered before the New York Academy of Melicine, November $7 t h$, 1855. By JoHn Watson, M.D., Surgeon to the New York Hospital. Published by order of the Academy.-New York, 1856. 8 vo, pp. 222.

THAT an acquaintance with the chief particulars in the History of Medicine from its birth or origin, onwards, should be regarded as an $39-x x$.

* Histoire de la Société Française pendant la Directoire. Paris, 1854. 
indispensable complement of the well-informed physician or surgeon, probably all will be found willing to acknowledge. When, however, we consider what means have been employed, and what facilities provided, to enable the earnest student of his profession to overcome the difficulties, and to assist him in the research and observation so requisite for obtaining a satisfactory knowledge of this subject, we find few landmarks to guide him. In it our English literature has been hitherto far from varied or accurate, while, complete as the opportunities for the instruction of students of medicine by lectures have become in every other essential department, in this they have been at all times acknowledged as deficient. To a certain extent the neglect of the History of Medicine, as an important subject of professional instruction, has prevailed in other countries than our own; but, considering the fame which Great Britain has acquired in the cultivation of Scientific Medicine, it is impossible to suggest this as an excuse for an essential element of the physician's and surgeon's education being overlooked. Strictly speaking, indeed, the great medical schools of our country are in this particular very greatly behind those of the Continent; for though the study of the History of Medicine is nowhere among the latter prescribed as imperative, in Paris, as well as Berlin and other German cities, lectures upon it are delivered; while even at Athens, in no degree famous as a medical school, the History of Medicine forms the subject of a distinct course of prelections. Apart altogether from the interest which necessarily pertains to a subject extending, as the History of Medicine does, from the very earliest to the present time, occupied with almost every country and nation of men, not excepting the rude and uncivilized, a knowledge of Medical History is calculated to secure the establishment of what alone is true, or at all events well founded; and that physician or surgeon who has undergone the additional mental culture it implies, is undoubtedly in a better position for the avoidance of error and for the rejection of unsound views. The consideration of the doctrines, theories, and practice of former races of physicians and surgeons, interesting as they must be, will also be eminently serviceable; and for the physician and surgeon now, we can conceive no duty more agreeable, and none more profitable, than the contemplation and comparison of the views of their predecessors. Such was the habit of the illustrious and the learned Scarpa: "Fu mai sempre mio costume nell" esercizio della chirurgia di confrontare le mie osservazioni con quelle dei più accreditati Maestri dell' arte che in ogni età fiorirono."*

We have spoken of the deficiency of our English literature upon the subject of Medical History, and, compared with that of France or Germany, it is indeed limited. We possess no such large or complete works as those of Le Clerc, Portal, Sprengel, Hecker or Haeser. In our language, the smaller works of Friend-which in some respects may be regarded as a continuation of Le Clerc's-Hamilton, Walker, William Black, and Moir, are those hitherto chiefly known and consulted. The absence of any complete and altogether trustworthy

* Trattato delle principale Malattie degli occhi. 
guide to the English student of Medical History must not, however, be considered to argue the want of individuals from time to time qualified for the duties of its authorship. Though we possess no extended History of Medicine, there are many admirable works in our language upon particular branches of the subject, greater or smaller, while the recent appearance of Dr. Wise's learned work on Hindoo Medicine," and the various highly interesting contributions of $\mathrm{Dr}$. Simpson, in illustration and elucidation of Greek and Roman physic, prove that with us an increased attention is being directed to it. Of late years, too, the indefatigable labours of Daremberg and Littré, in France, of De Renzi and the late Professor Vulpes at Naples, throwing light upon previously dark and obscure periods of the History of Medicine, and bringing to light in all their excellence the treasures of its ancient and forgotten heroes, have been worthily followed by Greenhill, Adams, and others, in our own country.

It is expressly from the conviction of the deficiency of the English language in works on the History of Medicine, that we are indebted to Dr. Comegys for the excellent translation of the comparatively recent work of Renouard, the title of which is placed at the head of this article. With it we have associated the very able discourse on the Medical Profession in Ancient Times, by another American physician, Dr. John Watson-an essay which we have perused with much pleasure, and which is calculated to shed additional lustre on the distinguished body before whom it was delivered. It is not a little remarkable that for these, the two most recent additions to our historical medical literature-one original, the other a translation from the French-we have to thank our American brethren. Aided by the labours of Dr. Watson and M. Renouard, and appealing to the writings of others, we shall endeavour to signalize what, in our opinion, are some of the chief points of importance and of interest in one of the most instructive portions of the History of Ancient Medicine, whether regarded by the enlightened practitioner or the student of medicine. Our readers may perhaps be inclined to start at the magnitude of the task we have thus proposed to ourselves, but in the present article we have no further object than to enlist their sympathies in the scheme of making instruction in the History of Medicine to be regarded as an essential of professional education, in something of the same light as the History of the Church is looked upon in schools of divinity. How much is due to the early cultivators of our science-how great the debt we owe to Hippocrates, for example,-can only be truly appreciated by him who has made the History of Medicine, antecedent to its great father and since his time, the subject of careful study.

It is interesting to observe how in all ages the question of the probable origin of medicine has occupied the attention of those who have themselves advanced the science. That, indeed, may be traced back to the very infancy of the human family - to a period regarding which we have no historical account, and possess only what Sprengel terms fabelhafte Ueberlieferungen.t Into the speculations which this inquiry

* Termed by Haeser, in his 'Lehrbuch der Geschichte der Medicin,' " eine sehr gediegene Arbeit."

† Versuch einer Pragmatischen Geschichte der Arzneikunde. Erster Theil, p. 19. 
has given rise to, we shall not enter, though at many times it has been discussed with very great learning, talent, and acuteness. Van Helmont, in his remarkable work, entitled 'Ortus Medicinæ,' \&c., and Le Clerc, in the work already alluded to, 'Histoire de la Médecine ou l'on voit l'origine et les progrès de cet Art, de siècle en siècle,' \&c., may with much advantage be consulted; and not less so the remarks in the treatise 'On Ancient Medicine,' one of the Hippocratic collection. That the origin of medicine may legitimately be traced to motions of the human intellect, and need not be attributed, as some have attempted to do, to a direct divine communication to man, is rendered probable from the circumstance that a variety, rude indeed, and oftentimes most uncouth, of medical and surgical practice has invariably been found to exist in newly-discovered countries, even though at the period of their discovery these have been sunk in the most degraded barbarism. Judging from this fact alone, we should feel inclined to adopt the opinion that medicine in its origin was coeval with man, or, as Le Clerc has observed, "Le premier homme a été en un certain sens le premier Médecin. ${ }^{2 \%}$

We cannot in this article devote space to the consideration of Primitive Medicine-a subject which, though possessing much intrinsic interest, has only that charm to reward our speculation, as it cannot be maintained that the progress of mythological medicine among the Hindoos, Chinese, and other nations, has any intimate relation with the real advance of our science. If we turn to ancient Egypt, a country in which we know the arts of civilized life to have been very early cultivated, there can be little doubt that the profession of medicine existed in it. The first physicians of Egypt were the priests; of their practice, and indeed of the constitution of their order, the knowledge we possess is limited; but this we do know, that medicine in Egypt was blended with superstition, and mixed up with all kinds of religious and fanatic observances. It was practised

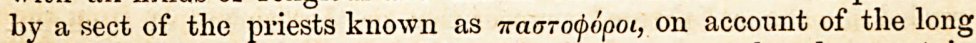
vestures which they wore, and because they were employed on certain ceremonial days in carrying the bed of the goddess Venus. These medical priests, we have reason to believe, were treated with great respect, and this we can the more readily understand when we consider that the occurrence of diseases was viewed by the Egyptians, just as it was afterwards by the early inhabitants of Greece and Italy, as a direct manifestation of the displeasure and interposition of their deities, and being thus assured they would naturally look to the ministers of these deities, the officiating priests of their temples, to be the means, if only indirectly, of procuring their removal. In this way it probably was that the priests of Egypt became Egypt's first physicians. That a subdivision of labour existed, that something resembling the specialities of the present day obtained among the Egyptians, we learn from Herodotus.

"The art of medicine (he says) is thus divided amongst them; each physician applies himself to one disease only, and not more. All places abound in plyysicians; some physicians are for the eyes, others for the head, others

* Histoire de la Médecine. Première partie, p. 7 . 
for the teeth, others for the parts about the belly, and others for internal disorders." *

The embalmers, whose handiwork has itself made Egypt famous, and has astonished and perplexed modern nations, probably were included among the medical priests. Of them Dr. Watson remarks, that,-

"Their occupation must have rendered them familiar with the internal structure of the body, and furnished them with useful insight into the nature, causes, and results of diseased action." (p. 16.)

For our own part, we confess that the account Herodotust gives of the operation of embalming - the brains being drawn through the nostrils by an iron hook, and the incision in the side being made by means of a sharp stone-leads us to the belief that notwithstanding the frequency with which the operation of embalming was performed, little satisfactory knowledge could be gained from it. Indeed, it appears to have partaken much more of a religious than of a medical character, and was very probably not performed by the same class of priests who were charged with the treatment of disease. It is true that we read in Genesis, fiftieth chapter, "And Joseph commanded his servants, the physicians, to embalm his father: and the physicians embalmed Israel." But various learned commentators on this passage in the Old Testament, and among others, Bishop Kidder, have regarded the Hebrew word translated physicians to signify those merely to whom the care of embalming belonged. $\ddagger$ Contemporaneous with the Egyptian there was another nation, of whose history in many important particulars the sacred writings authoritatively inform us, concerning whom and whose institutions, therefore, we are not left in the same degree of doubt. We know that civilization with its attendant improvements and advances in the arts and sciences, had made very considerable progress in Egypt before the family of Israel, compelled by famine, were driven to take refuge there. And such being the case, we would naturally expect that the Jewish people, from their contact and intimate relationship with the Egyptians, during fully four hundred years, would receive from them much of that knowledge and skill with which they were endowed. In the writings of Moses we find abundant proof that, as in the case of the Egyptians, the Jewish priests were originally the physicians. It was to the Levites the people applied when affected by leprosy; from them the infected sought a cure; it was the priests who determined what individuals and families were to do.

"When a man shall have in the skin of his flesh a rising, a scab or bright spot, and it be in the skin of his flesh, like the plague of leprosy, then shall he be brought unto Aaron the priest, or unto one of his sons the priests; and the priest shall look on the plague in the skin of the flesh; and when the hair in the plague is turned white, and the plague in sight be deeper than the skin of the flesh, it is a plague of leprosy, and the priest shall look upon him and pronounce him unclean."

In this passage of the thirteenth chapter of Leviticus, and in what follows in that and the succeeding chapter regarding leprosy, we have

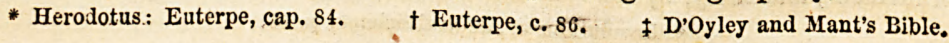


a striking example of the power committed to the priests: they decided as to the nature of the disease-leprosy or not; and consequent on that decision was the course which they again ordered to be followed and observed. Nor is it in connexion with the disease of leprosy merely that the medical functions of the Jewish priests is exhibited. Regarding the precepts contained in the twelfth and fifteenth chapters of Leviticus, Renouard truly observes, that after their perusal, "one cannot repress a sentiment of admiration for the wisdom and foresight which made such salutary regulations a religious duty." (p. 33.) How long the Jewish priests continued to be physicians also, we are unable accurately to determine. In the Apocryphal book of Ecclesiasticus, 38 th chapter, which has, from its style, been attributed to Solomon, but which, in any case, was written two hundred years before the birth of Christ, mention is for the first time made of the office of physician apart from that of priest.

"Honour a physician with the honour due unto lim for the uses which ye may have of him, for the Lord hath created him. For of the Most High cometh healing, and he shall receive honour of the king."

Passing now from this rapid glance at the condition of medicine in Egypt and among the Jews, we have to view it in Greece, still mythical and priest-ridden, antecedent to the Trojan war, and to that period in which, among the Greeks, we find materials the most ample and the most instructive for the history of medicine. Here it is unnecessary to follow the example of Le Clerc and Sprengel, and trace the history of the medical mythology of Greece, or even to mention the names of the numerous gods and goddesses, heroes or heroines, who were regarded as the inventors or cultivators of the various branches of medicine. Some of these-as Thoth, whom the Greeks called Hermes, and Isis-were borrowed from the Egyptians, others were of purely Grecian origin.

Leaving the period of mystic and primitive medicine, and in order to form a proper estimate of what the genius of Hippocrates effected for our science, we may now briefly inquire into the condition of medicine antecedent to the birth of him who has in all ages been. truly regarded as its father, limiting this inquiry still further by directing our present attention to the temples of AEsculapius, which, as Dr. Watson observes, " notwithstanding: the speculations of philosophers, and the trainings of the Palestræ; were thie first great foundations of medical knowledge among the Greeks." (p. 35:)

The priests of the temples of Asculapius or Asclepiadæ; knew well how to take advantage both of natural situation for their erection, and of the respect-amounting, indeed, to a feeling of veneration-with which they were regarded by those who sought their precincts. Cabanis has well observed, that -

"Many cures must have been accomplished by the diversion which the patients experienced in their journeys to these temples, by an exercise to which perhaps they had been but little accustomed; by the invigorating effects which an elevated situation produces on man, and indeed upon the generality of animals ; and lastly, by the still more invigorating effects of hope."**

* Revolutions of Medical Science, p. 53. 
But besides such methods of securing or promoting health as have now been referred to, and which may be classed under the head of Asclepiadæan hygiène, there is reason to believe that the priests of the temples or Asclepions resorted to various means of cure, according. to their notion of the particular ailments under which the patients who consulted the divinity laboured. The Asclepiadre we know prescribed bloodletting in certain cases, purgation or vomits in others, while friction, sea-bathing, and the use of mineral waters, were other remedies they often employed. Beyond all this, and exercising as it no doubt did a most powerful influence on the sick and on the sick folks' friends, was the mental influence which the doctor-priests of the temples knew only too well how to produce. Admission to the temples was forbidden to such as had not previously undergone certain means of purification; and when entrance was effected, the interrogation of the oracle was frequently delayed. Sometimes a day or a night, or two nights, were first spent, the patients meantime lying in the temples. Abstinence, prayers, fasting, sacrifices, followed. After all these preliminary rites had been gone through, and after the immolation of a ram or of a fowl, or, as at Cyrene, a goat, or at one of the other Asclepions any animal save this last, the will of the oracle was craved, and the response communicated by the priests.* At times but mysterious and uncertain information was conveyed. Sometimes the divinity deigned to appear under the form of a serpent devouring the cakes upon his altar; more frequently the eyes of the faithful and wondering sick were not treated to so close a manifestation of his presence. At certain times and on certain occasions the will of the god was communicated in dreams, and these were interpreted by the priests. The importance attributed to dreams, even at a later period, may be judged of by a perusal of the Hippocratic treatise " $\pi \varepsilon \rho \dot{~ \varepsilon ́ ย v v \pi \nu i ́ \omega \nu . " ~}$

The chief, and at the same time the most celebrated temples of Assculapius were those at Epidaurus in the Peloponnesus, at Pergamos in Asia, at Rhodes on the island of Cos, at Cnidos, and at Cyrene, a city of Lybia. Besides these, there were numerous others, both in Greece proper and in the Grecian dependencies. Schulze, under the head of "Notitia Asclepiorum," mentions and describes alphabetically little short of a hundred. $t$ It was customary for the priests in the Asclepions to report to new comers the history of the extraordinary cures which had been effected for former invalids, and particularly to signalize those cases which appeared in any degree to tally with theirs. The walls and pillars of the temples-and this is especially known to have been the case in those of Cos and of Cnidos, which was burnt in Hippocrates' time - were covered with inscriptions, detailing in shorter or longer terms the history of the diseases and the nature of the remedies which had at the advice of the deity been employed in these cases. Metal, marble, wood, stone, may all have been used for this purpose, according, probably, to the circumstances of affluence or poverty

* It was a cock that Socrates (according to Plato), in his last interview with his friends, requested them to offer for him to Assculapius.

+ Historia Medicinæ a rerum initio ad annum urbis Romæ Dxxxv., p. 118. 
in which the benefited parties were placed. Those who have visited the parish churches in the different Roman-catholic countries of the Continent, and more especially Southern Italy, will call to remembrance the manner in which the walls and pillars are covered by the so-called votive offerings, and will at once recognise in the ancient practice of the Grecian temples the quarter from which the latter may reasonably be assumed to have sprung. Scanty as the information was that these tablets conveyed, and better calculated, as they no doubt were, to fortify the piety of the faithful, than for any great end in the advancement of science, still we feel disposed to agree in the reflection of the learned author of the 'Revolutions of Medical Science,' that-

"However imperfect these descriptions of diseases and of their methods of cure may have been, their collection was nevertheless very valuable. They formed, as it were, the first rudiments of the art, and discovered some faint traces of the method of observation and experiment which alone is capable of placing it on a solid basis."

Antecedent to the time of Hippocrates, to which we have now to turn, a great revolution had been effected for medicine by the first or early philosophers, and of these Pythagoras, Heraclitus, and Democritus were the chief. Into the consideration of their particular views we cannot here enter, but it is only due to these philosophers to accord to them the merit of having secured in great measure for medicine its release and freedom from superstition. "They," says Cabanis, "transformed an occult and sacerdotal doctrine into a popular science, into a common art." In the four hundred and sixtieth year before the birth of Christ, Hippocrates, according to very general belief and expressed opinion, was born. Of the personal history of Hippocrates we know but little; that little, however, is so familiar to all, as to render it unnecessary here to recount it. As regards not a few of the particulars of his life and education, as well as of his doctrines and practice, differences of opinion among those who have made such the subjects of a peculiar and attentive study has prevailed;-to these Dr. Watson and M. Renouard allude, and we conceive that it would be the duty of a lecturer on the History of Medicine, after a careful investigation of the views entertained by all competent authorities, to unfold them; for assuredly it may at once be conceded that anything relating to the history of Hippocrates- " that divine old man," as Sydenham has expressively named him -is worthy of attentive consideration. When we consider the age in which Hippocrates lived, that at the period in question anatomy was scarcely practised; that physiology was virtually unknown; that with the exception of a few articles in the vegetable materia medica of Greece alone, was he able to find remedies wherewith to combat diseases, though it was in the operations of Nature herself he chiefly confided: in the contemplation of his life and labours, surely we find abundant proof of his genius and true greatness. What was known before his time was small indeed, not entitling medicine to be dignified by the name of a science. The consideration of what, during subsequent ages, has been added to the stores of knowledge he collected-what has been taken from these stores 
as inaccurate and unimportant - leads to the conviction which has in all ages been acknowledged, that by Hippocrates an era in medicine was formed. It was the power of observation which he so largely possessed, and so conscientiously employed, which caused Hippocrates to differ from all who preceded, from many physicians who came after him-joined to his high intellect, his exalted morality, and kindness of heart-it was this observing power that made him what he was. It is impossible to read a page of the genuine writings of Hippocrates, to peruse a single case, without being struck with the truth of this remark. The observation of individual cases of disease, the recording of these, marking the changes undergone daily, sometimes oftener, may have been, indeed very probably was, suggested to Hippocrates by the votive tablets deposited in the temples of Asculapius; but upon this, as Dr. Bostock* has well observed, "he so far improved as to be entitled to the merit of an inventor." And what was his invention other than the discovery of the method by which medicine is best studied, the patient is best ameliorated, the knowledge of the physician most extended? In all subsequent ages, too, this method gradually ripening to perfection, which it seems in our own day to have actually attained, has been regarded as the best for teaching an acquaintance with medicine, clinical medicine-the study of individual cases of disease at the bed-side-had in reality its origin in and from Hippocrates. Again, Hippocrates was the first who carefully watched the "juvantia et lædentia," as they have since been termed. He narrowly noticed the effects, good or bad, of his remedial applications, and endeavoured to remove or palliate individual symptoms. In this particular he was no less a discoverer than in the former, and what he did then, the wisest and the best informed physicians in all ages since have continued to follow him in doing.

Such were the chief improvements which Hippocrates introduced into, or effected for medicine; he pointed out that the first and great aim of the physician is to watch the operations of nature. He demonstrated the worthlessness of crude theories, and established incontestably that observation is the sole basis or foundation of medicine. The healingartin the hands of Hippocrates was, by his genius, and his genius alone, raised to the dignity of a science of experience and of facts. That distinguished position once acquired for medicine has never been lost. Regarding inedicine " as a principle of humanity, and not merely as a means for attaining profit and glory," Hippocrates was not content to instruct those of his own family alone-the plan followed by the Asclepiadæ-in the precious truths he had himself acquired, and therefore he earnestly desired, and eagerly sought to conımunicate his knowledge to strangers, and to those who had no claims of kindred to interest him in them. In this respect we may regard Hippocrates as the first and the greatest of medical reformers. Actuated by his genius no less than by his humanity, he soon saw the propriety, the necessity, indeed, of breaking through the system of unphilosophical exclusion which confined the physicians of Greece, as it were, to a single family. Can we doubt that the bold determina-

* See his admirable article, prefixed to the Cyclopædia of Practical Medicine. 
tion he then formed, and the means he must have taken to carry it into execution, would procure for Hippocrates much odium, and array against him many enemies, particularly among the Asclepiadæ, whose hereditary, and as they fondly imagined, inalienable rights he had so ruthlessly assailed. And when he had effected the reform he aimed at, when not only the Greek, free from the trammels of an Asclepiadean oath, though rejoicing to subscribe the Hippocratic declaration contained in the "Opros; but the stranger, it mattered not from where, could avail himself of his instructions, and following these out, could devote himself to the practice of the healing art, we can only faintly imagine what may have been the thoughts which occurred to the mind, what the emotions which animated the breast of Hippocrates, not yet aged, and we can in some degree only comprehend the zest and the energy, as Le Clerc says, "le ferment," that would be thereby diffused among his pupils. Some of the pupils of Hippocrates became his most distinguished successors, and various members of his own family, more especially his son-in-law, Polybus, worthily supported the character he had acquired. To most of his contemporaries, perhaps Le Clerc is warranted in concluding, that the words of Hippocrates himself were appropriate, "Qu'il y avait plusieurs médecins de nom, mais peu qui le fussent en effet."* There can, too, be little doubt that the lustre of his great name very nearly, if not completely, obscured theirs. This period in the history of medicine differs in no respect from that of any other, for, as has always happened, not only in it, but in other departments of human knowledge, the advance in the science and the improvements which he introduced into practice seemed, as it were, sufficient for centuries, and for such a period, in no considerable degree, were these advanced beyond the limit of perfection to which Hippocrates had brought them. Mr. Moir has well remarked :

"It happened with Hippocrates in medicine, as with Chaucer in English literature, that he not only far ontstripped the age in which he lived, but left many succeeding generations without the hope of rivalling his excellences."

Into an examination of the Hippocratic writings it is foreign to our purpose to enter, but, as affording the ablest and most complete view of these, we beg to refer our readers to what has been written upon the subject by Dr. Greenhill, + Dr. Adams, ‘ and M. Littré.\$ Dr. Watson only does the latter justice, when he speaks of his examination of the whole collection as " most careful and searching."

Thirty years after the birth of the father of medicine, and just at the time when his fame was beginning to be spread abroad, a great philosopher was born whose name was destined to be known till the end of time; this was "the divine Plato," who, like Pythagoras and Democritus before him, and Aristotle shortly after, though not embracing the profession of medicine, applied himself to the study of

* Histoire de la Médecine, chap. xxxiii.

+ Dictionary of Greek and Roman Biography and Mythology. By William Smith,

LL.D. Article, Hippocrates.

$\mp$ His admirable edition of the Works for the Sydenham Society.

$\S$ Oeurres Complètes d'Hippocrate. Traduction nouvelle. 
various things concerning the theory of medicine, and more particularly the economy of the human body, and the elements of which it is composed. No distinct treatise on medicine was written by Plato, but numerous references to it exist in several of his works. It is evident that he diligently studied the writings of Hippocrates, though in so far as the advancement of medicine by any new observation, or the suggestion of any reasonable theory is concerned, he cannot be said to have profited much by the study. But at present we cannot consider the doctrines of Plato and Aristotle, any more than those of Pythagoras, of whom we have already spoken. Regarding Aristotle, there is no doubt that the original character of his mind, the special advantages which he enjoyed, and the pursuits in which he engaged, rendered him better qualified than was Plato for conferring advantages on the science of medicine. The connexion of these two and other philosophers with medicine may be traced to the circumstance of a knowledge of its science having at that time been looked upon in Greece as one of the requirements of a polite or general education. In so far as anatomy and physiology are concerned, it will now be pretty generally admitted that they should form branches of that general stock of knowledge towards the attainment of which the liberally educated ought to aim ; and it may not without reason be presumed that, were some general ideas in regard to the nature and treatment of diseases included in the category, we should find that the gratifying result of an increased reliance upon the skill of the thoroughly educated and competent physician, and of a gradual decline in the hideous refuge of quackery to which so very many presently resort, would follow.

As the father of medicine founded the science of medicine, so may his immediate descendants, more especially Thessalus, Polybus, Draco, and Prodicus, be said to have founded the first medical school based upon rational principles. It has been indifferently called the Hippocratian or the Dogmatic School, the sect of the Dogmatists. Belonging to this school was Diocles, of whom Galen frequently speaks in high terms, and who, along with certain other distinguished cultivators of medicine, is thus alluded to by Celsus: 'Post quem Diocles Carystius, deinde Praxagoras et Chrysippus, tum Herophilus et Erasistratus, sic artem hanc exercuerunt ut etiam in diversas curandi vias processerint." The two last named physicians were the most distinguished of those who adorned the Alexandrian school of medicine. The death of that renowned king, whose name the city received and still bears, occurred at the early age of thirty-two, about seven years after its foundation, and 324 years B.c. After this event the vast empire of the Macedonian conqueror was dismembered, and in the year 321 B.c., Ptolemy the First, surnamed " $\sigma \omega \tau \eta \dot{\rho} \rho$," half-brother of Alexander the Great, because son of Philip, beeame king of Egypt. He was the first of that dynasty of Greek kings in Egypt who conceived

"Truly a royal idea," says Renouard, "and worthy of the successors of Alexander, that of collecting together all the intellectual riches of the universe, and placing them at the disposal of studious men, who were desirous to use them for their improvement and the advancement of science." (p. 166.)

* Liber 1, Prxfatio. 
The library and museum of Alexandria, founded by the first Ptolemy, received under the patronage of his successors numerous valuable additions. The literature of all nations was to be found in the former. The library of Aristotle, at that time the largest private collection in the world, was acquired for it by purchase, till at length, according to Eusebius, the Alexandrian collection contained no fewer than one hundred thousand volumina or rolls. The Ptolemies, owing to the extensive commerce in which they engaged, were enabled to gather together, chiefly from the Indian Ocean and its shores, a multitude of plants and animals previously unknown and undiscovered, and these were submitted to the observation and investigation of naturalists. In this Alexandrian school, which the munificence of the Ptolemies founded and sustained, the science of medicine flourished; and it cannot be doubted that for several improvements we are indebted to its professors.

Anatomy and physiology received an impetus, which, undreamt of previously, must have filled with amazement those who witnessed the change effected-when Herophilus and Erasistratus, the two most renowned of the Alexandrian school, first openly practised the dissection of the human body. Upon the testimony of Celsus, it has been believed in all ages that vivisection was pursued by these two famous physicians. Celsus's words are, "qui (Herophilus et Erasistratus) nocentes homines à regibus ex carcere acceptos vivos inciderint."* By some they have been praised, by not a few, as by Tertullian, $t$ who in a curious passage styles Herophilus, "ille medicus aut lanius," condemned on account of the barbarity of their procedures. For our own part we are unwilling to believe that, under the sway of so enlightened potentates as the Alexandrian rulers, such enormities were ever practised. There appears no occasion for regarding a statement resting on the authority: of Celsus alone, though mentioned by Galen, and quoted by Cœlius Aurelianus and other authors, as an historical fact. It must be kept in view, that the performance of vivisection was brought as an accusation by Celsus against Herophilus and Erasistratus, leaders of the Dogmatic school-he himself evidently tending to the support of opposite opinions-and that, at a period long subsequent, similar accusations were repeated in the case of more than one of the earlier cultivators of anatomy. In the case of the latter, such accusations were without the vestige of a foundation to rest upon, and if not due to the malice and malignity of enemies, can only be ascribed to the scandal and tittle-tattle of busybodies, whose speeches, even though nowise meant, too often end in the propagation of what is slanderous and untrue. It appears to us as by no means improbable that Herophilus and Erasistratus, just as happened to the anatomists in more recent times, may, by the performance of some heroic operations, have given rise to the belief of their being engaged in proceedings which we naturally shrink from laying to the charge of men so deservedly famous in their profession. Concerning the personal history of these, the most distinguished of the Alexandrian professors, we know little that can be regarded as really accurate, but frequent allu-

* Liber 1 , Præfatio. † De Anima, c. 10. Ed. F. Oehler. Tome ii. p. 571. 
sions to their investigations, opinions, and practice are met with in Galen and in Coelius Aurelianus, who was nearly the contemporary of Galen. The latter speaks in the highest terms of what Herophilus did for anatomy; and while Erasistratus also appears to have been an accomplished anatomist, the fame of his colleague has excelled in the practical part of their common profession.

No period of the history of medicine is more interesting than that of the establishment of the Alexandrian school. An important event occurred in the history of medicine soon after its institution.

"At this time (writes Celsus) medicine was divided into three branchesone which cured by diet, victu; another by medicines, medicamentis; a third

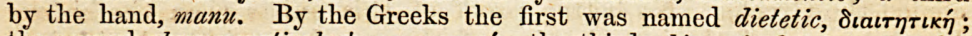

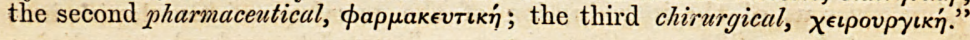

For the future, these divisions were distinct, and exercised by distinct parties, separate individuals. This was a great change. Previously, the same persons had acted in the capacities of physician and surgeon alike.

Shortly after the establishment of the Alexandrian school-that is, about three hundred and twenty years before Christ-the formation of the two rival sects, the Dogmatists and the Empirics, arose. "Hanc mox secuta est medicorum in sectas secessio," says Blumenbach, in his admirable synoptical introduction to the literary history of medicine, "præsertim in dogmaticam quod in medicina exercenda rationi multum tribuebat et empiricam quæ fere unice experientiæ confidebat."* The real matter of dispute in this controversy, at the time of its origin, and as somewhat altered, it has occupied men's minds since, and occupies them now, was, "how far is theory to be permitted to regulate practice?" Celsus, in an elaborate passage, $†$ has very candidly stated the case for both parties, though he evidently, as has already been noticed, favoured the empirics. To it and to the admirable account which Le Clerc has given of the rival sects, we must refer those interested in the inquiry; and further to two very elegant essays, entitled 'The Empiric and the Dogmatist,' by Dr. Thomas Percival. + The establishment and flourishing career of the school of Alexandria forms a very important chapter in the history of medicine. In it, during several centuries, a succession of learned men, not devoted to medicine alone, but to the other sciences as well, was produced, and thus the school became subservient to the advancement of knowledge and learning, and at all events prevented the decay into which, after the decline of Grecian literature, they were in no small danger of falling. But though during centuries the principal seat of medical learning, Alexandria was not the only school. Smyrna, Pergamus, and Epidaurus, during the same period attracted students, and these cities were visited by not a few of the more distinguished pupils of the Alexandrian teachers.

We must now pass very shortly to consider the rise and progress of medicine in Rome. Pliny informs us in terms the most distinct that for more than six centuries Rome was without physicians, $\ddagger$ an expression which, while it cannot be supposed to indicate what it literally

- Liber 1, Præfatio.

+ Essays.

\pm Liber xxix. chap. 1 . 
means, that no attempts were made to mitigate or to cure diseases, may be accepted as a very explicit notification, on the authority of one very well informed, that during six centuries there were in Rome no individuals eminent for their learning or skill in the healing art, or perhaps, that during that lengthened period, medicine was in no part of the vast territory of Rome regarded as the object of a distinet art or occupation.

By the famous Roman historian, Livy, who was born fifty-nine years B.C., and died A.D. 17, as well as by others, references are made which clearly indicate that in medicine, as in nearly every other subject relating to the arts of life, the Romans copied the Greeks. No better proof of this exists than the history Livy gives us of the introduction of the worship of Esculapius into Rome. "Anno 234 ante Christi natum," says Blumenbach, "medicina cum reliquis scientiis e Grecia Romam migravit."* The first physician who settled and practised at Rome was Archagatus, the son of Lysanias. He was born in the Peloponnesus, and appears to have entered the Eternal City during the consulate of Lucius AEmilius Paulus and Marcus Livius Salinator, in the year 535 from its foundation, or about 219 years before the birth of our Lord. Little is known of this, the first Roman physician. Pliny informs us that the privileges of citizenship were conferred upon him. $\mathrm{He}$ is alluded to under the title Vulnerarius, from which we may conclude that he was more devoted to the practice of surgery than that of medicine. Another title, but one by no means so complimentary, was conferred upon Archagatus-namely, Carnifex, murderer or executioner, on account of the unfeeling and even barbarous manner in which he is said to have treated his patients. $t$ The performance of some bold operation may in the first instance have led to the latter epithet being applied to Archagatus, a conjecture all the more likely to be correct when we reflect how common it has been in recent times, and even in our own day, to regard distinguished surgeons as necessarily cruel, or at all events, less humane than other mortals. That their being adepts in surgery should necessarily lead to such an issue, we need not say appears to us a complete non sequitur. We learn from a study of the early history of Rome, that the inhabitants regarded with feelings of envy, and oftentimes of hatred, the Greeks who had settled themselves down in Italy, and chiefly in the capital, no doubt like our modern emigrants, for the purpose of "bettering themselves." In the intensity of his dislike to the Grecian settlers, Marcus Porcius Cato, the censor, was at this time particularly distinguished. By Scipio Africanus, on the other hand, they are said to have been encouraged and protected. It has even been affirmed that by Cato the expulsion of the Greek physicians from Italy, just as in modern times the Jesuits have been banished the Eternal City, was meditated, if not actually put into execution. $\$$ About a century elapsed before we meet the name of any other physician in Rome who distinguished

* Op. cit.

† Plinii, op. cit.

‡ See Agrippa's Variety of Arts and Sciences, p. 297. For a view of this philosopher's hatred of physicians, see Mr. Morley's admirable Life of Cornelius Agrippa. 
himself; but about that time we do find one whose influence was widely exerted and proved most beneficial. "Primus vero medicorum Romanorum fama et meritis præcellens Asclepiades erat."* This physician was born 91 years B.c., was a native of Bithynia, and originally settled in Rome as a teacher of rhetoric, but being unsuccessful in this walk, at a comparatively late period of life he applied himself to the study of medicine. From what Galen and Coelius Aurelianus have recorded of Asclepiades, it is evident that he was a man possessed of very considerable talents and understanding. Like not a few practitioners of our own times, however, who, thirsting for professional success, are not very delicate in the means they employ, if only they obtain it, Asclepiades commended himself to public confidence by the very general condemnation - not unfrequently the unmeasured abuse-with which he assailed the practice of his contemporaries, and the disparaging manner in which he spoke of the doctrines of his predecessors - even those of Hippocrates himself. This was the method Asclepiades adopted, and whether or not his success was due to his sagacity, of the fact of his great popularity there can be no doubt. He was totally ignorant of anatomy, and was foremost in proclaiming the inutility of anatomical and pathological investigations. His merits have been very differently estimated by different authors. + There can, however, be no doubt that he was instrumental in advancing the boundaries of medical knowledge. Of him Celsus says, "Asclepiades officium esse medici dicit, ut tuto, ut celeriter, ut jucunde curet," a phrase which may be said to have become proverbial in the profession. He employed the lancet in the acute diseases of the chest which were accompanied by pain, but in those only; he incised the tonsils, and was the first to perform the important operations of laryngotomy and tracheotomy, of which Coelius Aurelianus nearly two centuries thereafter writes in terms indicating his idea of the extreme rashness of Asclepiades, and further characterizes the operation as one which should never be performed. He it is who first divided diseases under the names of acute and chronic. Another important doctrine of Asclepiades is thus well expressed by Dr. Watson, "the self-limitation of diseases, asserting that the principal cure for a fever was the disease itself." (p. 101.)

The immediate successors of Asclepiades were Themison, the originator of the Metlodic school, who held views midway between the Dogmatists on the one hand and the Empirics on the other; Antonius Musa, to whom Plinył refers; and Cassius, whom Celsusફ styles "ingeniosissimus seculi nostri medicus." Of these and others we cannot now speak, and pass to a brief notice of him who has been justly designated the Latin Hippocrates Aulus, or Aurelius Cornelius Celsus, the first native Roman who wrote on medicine, for previously to his time the physicians in Rome who had attained to eminence were Greeks or Asiatics, is most generally considered not to have been a regular member of the medical profession, but as having devoted himself to the

* Blumenbach, op. cit.

† By Cacchi (in his Discorso supra Asclepiade, Firenze, 1758) he is styled "Uno dei più excellenti e più fortunati uomini dell' antichità.

$\ddagger$ Historia Naturalis, lib. xix. chap. 8.

§ Celsus: lib. i., præfatio. 
study of many things connected with the theory and practice of medicine. Judging from his writings, 'De re Medica,' it is indeed difficult to believe that Celsus was a mere dilettante in physic; but it must be remembered that by his contemporaries his works on rhetoric and agriculture seem to have been equally prized," while their author was respected as a most learned man-one who studied natural history in all its varied departments, and attained an excellent understanding in each.

Celsus was, in all probability, born in Rome, though by some Verona has been considered the place of his birth. That event occurred within the first few years of the era, and most likely in the year 4. We have the authority of Galen for stating that Celsus received an excellent education. By the attentive student of his writings, however, no such authority is required: the perusal of these forces the conviction. By some authorities it has been supposed that Celsus acted as secretary to the Emperor Tiberius when on his expedition to the east, and they imagine this view to receive confirmation from the circumstance of Horace, in his epistle to Julius Florus; mentioning the compilations which a certain Celsus made from the library of Mount Palatine.

\section{"Quid mihi Celsus agit? Monitus multumque monendus, Privatas ut quærat opes, et tangere vitet, Scripta, Palatinus quæcumque recepit Apollo ;"†}

They further endeavour to establish the existence of an intimate relationship between Celsus and Ovid. It is greatly to be regretted that all the works of this distinguished author have not been spared to us. At the same time we may truly congratulate ourselves on the possession of the treatise, 'De re Medica, libri octo,' and reasonably regard it as a chef d'ceuvre.t. Into a discussion of this work, so well known and so thoroughly appreciated, it is here altogether unnecessary to enter. The most interesting portions are undoubtedly those devoted to surgery. Hippocrates and Asclepiades are the two authors to whom Celsus is chiefly indebted. In his system of prognostics, which, in ancient times, was not employed in the limited sense in which we now use the term prognosis, but was significant of all the phenomena of disease, as the master mind and observing power of Hippocrates had traced them,-Celsus was at one with the father of medicine, also in respect to the nature and treatment of surgical maladies. Many passages on these subjects are literal translations from Hippocrates; and it very probably was from the known respect he entertained for the Coan physician, and the frequent allusion to his writings and quotations from them, that the title "Hippocrates Latinorum" came

* It has not always been considered so, however. Quintilian makes the following foolish and ill-natured remark. "Quid plura? cum etiam Cornelius Celsus mediocri vir ingenio non solum de his omnibus conscripserit artibus, sed amplius rei militaris et rusticx etiam, et medicinæ præcepta reliquerit? dignus vel ipso proposito, ut eum scisse omnia illa credamus. Lib. xii. ch. xi.

† Epistolarum lib. i. 3, 1. 15.

$\ddagger$ For a long period the treatise ' De re Medica' was regarded as complete: the celebrated Morgagni, towards the commencement of last century, had the merit of discorering that the fourth book was incomplete, and that the hiatus was of a considerable extent. 
to be applied to Celsus. The references to Asclepiades, particularly in the earlier books, are frequent. Not unfrequently he differs on important topics from him; but Celsus applies the title of a good author to Asclepiades, and his opinions he evidently respected as those of a sagacious physician. Next to these, Celsus most frequently aliudes to the views and practice of Themison, his contemporary, and of the learned and distinguished teachers of the Alexandrian school, Herophilus and Erasistratus. But though evidently an earnest admirer, Celsus was no blind follower of Hippocrates. Like Asclepiades, he - rejected the theory regarding critical days-a most important part of the Hippocratic doctrine as respects fevers and other acute diseases; and after giving a short but comprehensive and decided statement, in the third book, * of his own views as opposed to those of the Father of Medicine, he thus sums up:- "Adeo apparet, quacunque ratione ad numerum respexerimus, nihil rationis sub illo quidem auctore (i.e., Hippocrates) reperiri."

At the period when Celsus flourished, surgery had made very considerable progress. Many of those operations which we denominate the grand or capital operations of surgery are minutely described in his pages, and were evidently practised with success in his time. Of late years an additional amount of interest has been thrown upon the subject of the surgery of ancient Rome, from the circumstance of the discovery of numerous surgical instruments in the excavations at Herculaneum and Pompeii. When it is remembered that these Roman cities were at a distance from the capital which cannot have exceeded a few days' journey at the time, and that at the very period of their overthrow (A.D. 79) Celsus was alive in Rome, very probably engaged in writing the treatise 'De re Medica', it is highly probable, if not absolutely certain, that the same surgical instruments which were in the hands of the practitioners at Rome would be possessed by their brethren then exercising their art at Herculaneum and Pompeii. In illustration of this-a subject to which neither M. Renouard nor Dr. Watson have had their attention called-we must, for the present, merely refer our readers to the labours of the late Professor Vulpes, of Naples, who with untiring diligence examined all the discovered instruments, and by his well-directed efforts has conferred a substantial benefit on the history of surgery. + Of the practitioners in Rome contemporary with Celsus and those who flourished during the first and second centuries, we cannot now write in detail. During that period the capital of the world gave rise to no native author of distinction on any of the branches of the art of healing. The knowledge we possess of the condition of the Roman empire, and of the state of the medical profession in it, as well as more precise information regarding individual physicians and surgeons of the period, is due in no smali measure to the illustrious Caius Plinius Secundus, Pliny the elder,

* Chap. iv.

+ Illustrazione di tutti gli Strumenti Chirurgici scavati in Ercolano e in Pompeii e che ora conservansi nel Real Museo Borbonico di Napoli. For notices of this work see Dublin Quarterly Journal of Jedical Science, August, 1852; and Edinburgh Monthly Journal, August, 1853. 
who, in his immortal work, 'Historia Naturalis,' has especially made us acquainted with the medicinal plants then in use, the medicines derived from the animal kingdom, and further, with very interesting particulars regarding many diseases, commencing, as Book twentysixth does, with the affection lichen, or mentagra, which is supposed by some to have been identical with the venereal disease.

Regarding the interval of time which extended from Asclepiades to Galen, abont two hundred and fifty years, Dr. Watson well observes that it was "one of the most active periods in the whole history of our art."

"As such," he continues, "it is more worthy of notice, from the fact that the native Romans were never seriously devoted to the cultivation of the sciences. But quick discoverers of the useful, they knew how to improve upon the suggestions or discoveries of the Greeks. Their immense cloacæ for the drainage of the city, - their publie baths, - their care in the selection of sites for new towns, villas, and private residences, - their improvements in architecture, and the domestic arrangements of their dwellings, as set forth by Vitruvius and others, are sufficient to show that the lectures of their Grecian masters on the rules of health had been properly appreciated, and the informa. tion thus diffused among them turned to good account." (p. 142.)

During the same period distinguished men were born in various provinces or dependencies of the Roman empire. Of these none has enjoyed a greater amount of posthumous fame than Aretæus, surnamed the Cappadocian, from the place of his birth. Little is known of the personal history of this distinguished physician, Galen, strange to say, being entirely silent regarding him; there can be little doubt, however, that his literary and medical fame was not acquired among the mountains of his native Cappadocia, nor that a great part of his life was passed in Egypt, as Dr. Watson supposes; but that, like Archigenes born in Syria, and Galen in the city of Pergamos, prompted by a laudable ambition, he had early hastened to the Capital, "there," as Dr. Adams, his most recent biographer,* has observed; "to try his fortune in the great seat of empire."

As an author, Aretæus is distinguished for the combination of elegance and simplicity. By the moderns his works have been most highly esteemed. Haller seems to assign him even a higher niche than that he considers due to Hippocrates; Sprengel reckons him immediately after the Father of Medicine; and our countryman, Dr. Friend, seems to rank them together. Aretæus was an able defender and supporter, the most able, indeed, of the doctrines of the Pneumatics. The sect of the Pneumatics, originally founded by Athenæus of Attaleia, in Asia Minor, but a practitioner in Rome, centred their belief in the body being constituted of solids, fluids, and pneuma or spirits. Upon the due correspondence and proper relationship of these three constituent elements depended health. Like Aristotle and the Stoics, whose doctrines in the time of Aretrus, patronized by the Roman Emperor Antoninus, were held in high repute, he regarded the "pneuma" as passing from the lungs to the heart, and thence by the arteries distributed to all parts of the system. The heart he re-

* Sẹ an interesting sketch in the works of Aretxus, edited for the Sydenlam Society. 
garded as the focus, or central point of the vital force and of the soul. The qualities of the pneuma he looked upon as mainly determining the nature of most diseases-a dense pneuma producing organic obstruetions. Thus, in the first book of the treatise on chronic diseases, and in the chapter " $\pi \varepsilon \rho \iota \Sigma \pi \lambda \tilde{\eta} \nu o$," Aretæus observes, "Even to its upper parts the abdomen is filled with a pneuma, thick, misty, humid in appearance, but not in reality."

About the same time as the Cappadocian, there flourished the author of the only complete treatise on the Materia Medica which has been handed down to us from antiquity-Pedacius Dioscorides. It is true that before the birth of this eminent man there were many physicians and others who had occupied themselves with the examination and investigation of the substances used in medicine; but comparatively little was known before his day, and no exact information had been collected. Prior to Dioscorides there had been, among others, the two Andromachi, father and son, to whom a remarkable prominence is given by Galen. The father was physician to the Emperor

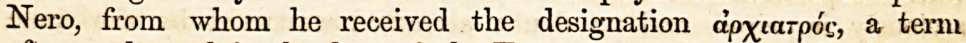
afterwards used in the days of the Emperors to denote a physician of unusual eminence. He must have lived very shortly before Galen, as we find the latter thus writing in regard to him: "Andromachus vir mehercule memorabilis nec multo ante nos natus."* Anazarbia, a town in Cilicia, was the place of the birth of Dioscorides-an event which probably occurred in the latter half of the first century. In all ages the works of Dioscorides have been read and admired. Galen frequently refers to and quotes from them; by Oribasius, a learned physician of the fourth century, they are spoken of in the highest praise. Modern authors, too, have all contributed to do Dioscorides honour. As his works now exist, they contain five books on the Materia Medica, and two separate treatises, in which poisons, wounds inflicted by venomous animals, and their appropriate treatment or antidotes, are discussed. No ancient work on medicine, or its allied sciences, is more entitled to our study or regard, and certainly there are none which will more fully reward the attention bestowed upon it.

The condition of medicine in Rome during the second century is best judged by a consideration of the writings of that illustrious man whose genius and fame have secured for him the title of "the Prince of Physicians." Claudius Galen was born in the one hundred and thirty-first year of the Christian era, during the reign of the Emperor Hadrian, in the city of Pergamos, in Asia Minor, celebrated in inany respects, but more especially on account of the temple of Assculapius.

For our knowledge of the personal history of Galen, we are chiefly indebted to himself; he has been his own biographer, and materials ample enough, are supplied-not always judiciously, throughout his writings, to enable us to acquire a tolerably circumstantial view of his life. Into this we cannot now fully enter; a somewhat meagre account of it is given by Dr. Watson. It appears that by his father, 
Nicon, the dawning of genius in the youthful Galen was very early discovered, and that from the first no means were spared for quickening that promise which was afterwards so gloriously fulfilled. It was from the mere accident of a dream that Nicon changed the profession he had intended the son to pursue, from that of philosophy to medicine, and thus was secured to our science the possession of one of the greatest names which has adorned it in any age or clime. The professional education of Galen was of the most liberal and extensive description ; originally conducted in the city of his birth, he seems to have passed from Pergamos to Smyrna, thence to Corinth, and finally to Alexandria, at that time still deservedly eminent in the world of science. After a residence in Egypt, which must have extended over several years, Galen made a journey to Cilicia, Phœnicia, and Palestine, visited Scyros and Crete, and in his twenty-ninth year (A.D. 158) he again reached his native Pergamos.

On the occurrence of a revolutionary movement, probably judging that his position and means of professional advancement would be seriously impaired, and no doubt attracted westward by the fame which certain of the Greek physicians in Rome had acquired, he bent his course to the then capital of the world. Settled there, his reputation. immediately began to rise, and during the four years he remained, we find Galen to have been regarded by small minds with that degree of enmity and malignity which has ever been seen in this world's history, to be directed by them against those who, whether deservedly or otherwise, have rapidly attained to professional success.* In the work of Galen which we have referred to, abundant particulars regarding his life in Rome are afforded. It was, no doubt, by his successful lecturing and writing, and particularly by the success of his practice, that the envy and ill-will of the Roman physicians were drawn down upon him, and it was their determined hostility which induced him to escape from their machinations and from Rome at the same time. It has been said, indeed the charge has been frequently made, that Galen fled from Rome to avoid the plague, which, originating in the neighbourhood of Antioch in the year 166, and in its progress ravaging many parts of the Roman empire, finally reached the capital.t There can be little doubt that in the main this accusation, though perhaps receiving some sort of countenance from what Galen himself says in the 'De Libris Propriis,' cap. i., is groundless. Surely the whole of his after life and the character of Galen sufficiently contradict it. But at the same time, the fact of his leaving Rome just as the pestilence reached it, clearly shows that Galen regarded his life as very insecure in that city, owing to the eager rage of his enemies; and further, that his anxiety to revisit Pergamos, now that the revolution which had originally driven him from it was over ("seditione in patria mea sedata"), was also very great.

It was in 167 that Galen left Rome, but he had scarcely settled

* The language employed by Galen himself in his treatise 'De Prænotione ad Epigenem, being " Medicorum et Philosophorum in urbe malignitate."

$t$ This was the epidemic which Gibbon in his forcible language describes as " attacking with indiscriminate rage erery rank and profession." 
down to his usual mode of life in Pergamos, before he was summoned to attend the Emperors Marcus Aurelius and Lucius Verus, then at Aquileia in Venetia, the chief bulwark of Italy on the north-east frontier, whither they had gone to superintend the preparations for war with the northern tribes, and had resolved to spend the moriths of winter. Passing through Thrace and Macedonia, a journey which he performed on foot, for in the "De Simplicium Medicamentorum Facultatibus,' we read "eamque pene totam pedestri itinere pertranssivi," Galen, towards the close of the year 169, reached the camp of the Emperors, but to find it abandoned by both, owing to the pestilence, already referred to as so wide spread, having broken out with redoubled violence. The Emperor Verus died in the Venetian territory, of apoplexy; Galen accompanied Aurelius to Rome. Again rising high in public favour, and retaining the confidence of Aurelius, he was appointed by the Emperor physician to his son Commodus, then a boy, when he himself left Rome to prosecute his wars on the Danube. About this time two of his principal works formerly commenced were completed-viz., 'De usu Partium Corporis Humani,' and 'De Hippocratis et Platonis Decretis.' Galen once more revisited Pergamos, and finally died at an advanced age; when and where this event occurred is not, however, accurately known. Many authors, and among others Chartier, have stated that Galen, convinced by the miracles performed by the disciples of Christ, embraced the Christian religion, and that animated by the desire to visit the scene where these miracles were performed, he had set out on a voyage to Judea, but that owing to shipwreck or sudden illness, he never accomplished his design.* Such are some of the best authenticated circumstances with which we have become acquainted in regard to the personal history of one of the most illustrious physicians, as he was one of the ablest and most renowned men, who ever lived. Galen did not confine himself to the acquirement of professional knowledge alone : it is evident from his writings that he was philosopher no less than physician, and he particularly insisted on the necessity of all physicians being acquainted with other branches of knowledge in addition to medicine. Of his personal character, as exhibited in his writings, there is much to admire him for, and there are also some defects, otherwise he had not been mortal, to point out. He was certainly a most accomplished and very learned man, and seems to have been habitually deeply impressed with the gravity and high responsibility of the office of physician. But no doubt he had too high an opinion of his own great merits, and like all such as over-estimate their own good qualities, he expressed himself with a bitterness and contempt, which frequently became untrue besides unjust, of his personal opponents and contemporaries. For this failing on the part of Galen, living at the time he did, and unsoftened, as during the greater part of his active life he no doubt was, by the amenity and genial influence of Christianity, let us not forget that some apology at least is to be found.

The works which Galen bequeathed to the profession are as numerous as they are valuable, amounting to not fewer than two

* See Portal: Histoire de l'Anatomie et de la Chirurgie, vol. i. p. 92. 
hundred, while the information they contain and learning they display are such as to make it abundantly evident, that of his contemporaries there was no one who equalled him; that of the second century Galen was the facile princeps of medical writers and of physicians. The severity of our judgment may be extenuated regarding a man who so vehemently and systematically condemned the opinions and practice of others, when we reflect that, as was the case with Galen, he was immeasurably superior to all his contemporaries, of the "futility of whose reasoning" and "deficiency in their information" he was profoundly convinced. The result of all this was, that Galen attained to a rank in the medical world, and swayed the opinions of physicians and of the public on all points connected with medicine, in a manner before and since unknown. Hippocrates, it is true, had been recognised during his lifetime as the Father of Medicine; but in his day learning was confined to the few, and it required the development of man and his inventions, such as the establishment of the empire of Rome brought about, before a Galen could exist. For many centuries after his decease, the doctrines and tenets of Galen were, as Dr. Bostock well observes, "regarded very much in the light of oracles, which few persons had the courage to oppose."

According to Choulant, * who has made the so-called works of Galen a subject of special study, these consist of eighty-three treatises acknowledged to be genuine, nineteen whose genuineness has with more or less reason been doubted, forty-five undoubtedly spurious, and fifteen commentaries on different works of Hippocrates, while more than fifty short pieces and fragments (many or most of which are probably spurions), are still lying unpublished in the different libraries of Europe. Besides the works now referred to, many other treatises were written by Galen, of which nothing but the titles have been preserved. Dr. Greenhill believes that the total number of the Galenic writings cannot have been fewer than five hundred. $t$ The first edition of the collected works of Galen was published at Venice in 1521, in five volumes folio.‡ The best edition of the works of Galen is that of Kühn, in twenty volumes octavo, 1821-1833.

In judging of the particular views entertained by Galen, it must be remembered, that at the period when he began to study, the profession of medicine was divided by sezeral sects, these all disputing with one another. The Dogmatists and Empirics had long existed, but still the particular views of these two rival parties were upheld with an equal degree of tenacity and keenness to what had manifested itself in the days of Celsus, and before his time. About a century B.c. had arisen the Methodic sect, while very shortly before the time of Galen there had been established the Eclectics, Pneumatics, and Episynthetics. What is important in connexion with Galen to note is, that, unlike all the physicians of Rome who were his contempo-

* Handbuch der Bücherkunde für die Aeltere Medicin.

+ See his most interesting account of Galen, in Dr. Smith's Greek and Roman Biographical Dictionary.

‡ See Blumenbach, op. cit.; Haller, Bibliotheca Anatomica, tom. i.; and Dr. Greenhill, as above. 
raries, unlike all who had prececied him, he attached himself to none. "Nullius addictus jurare in verba magistri," he chose from the tenets of each what he 'believed to be true and most generally useful, but in no way did he connect himself with the Pneumatic or the Eelectic school, with the Dogmatists, Empirics, or Episynthetics. So far, however, as his general principles of professional action are concerned, Galen may truly be considered more of a Dogmatist than as belonging to any of the other sects. Of Hippocrates, Galen was a great admirer, yet he was no blind copyist, frequently differing from him, generally in no empty or vain spirit, assigning a reason, and in the majority of instances a legitimate one, for the variance. $\mathrm{He}$ despised those persons who attached themselves to any particular master. If we judge from the meagreness of his anatomical descriptions, and from the circumstance of his never referring to the dissection of the human body, we are entitled to conclude that this was a branch of professional inquiry which Galen had no opportunity of practising. Monkeys and other animals he did frequently examine anatomically.

Erasistratus and the disciples of the Alexandrian school conceived that the arteries contained no blood, but air; Galen, by experiments happily contrived and executed, determined that the arteries contained blood, and blood alone. "Ubi funiculo dissectam arteriam utrinque ligavimus, et quod in medio comprehensum fuerat incidimus, sanguine plenam ipsam esse monstravimus." This, then, was a most important discovery, and equally important and interesting is the account Galen gives of the function of respiration. Mons. Flourens has well observed in regard to it: "l'idée de Galien était un progrès, et tellement un progrès que, sur ce point, la physiologie tout entière n'a pu en faire un autre que par le secours de la nouvelle chimie."* " The pathology of Galen, though by no means so perfect as his physiology, is still worthy of attention; like the Father of Medicine, he supposes that in the fluids the primary cause of disease existed. As his foundation of reasoning, he adopts the doctrine of the four elements. The causes of disease he regarded as remote or at hand, and of these he gives a description not unlike our predisponent and excitant causes. The superabundance and the degeneration, but especially the putridity of the humours, Galen looked upon as the grand first causes of diseases. His practice was founded upon his pathology, and partakes of its excellences and errors.

Many of the cases recorded by Galen, though falling short in the interest excited by the simple and genuine manner of those detailed by Hippocrates, are instructive in no small degree. In particular diseases Galen adopted special modes of practice; but as a general rule his regimen, diet, and great part of his employment of medicines, resembled the plan followed by Hippocrates. At Pergamos, Galen appears to have acted both as physician and surgeon; but "in Rome he did as Rome did," and in conformity with the usage of the phy-

* Histoire de la Découverte de la Circulation du Sang, p. 5. 
sicians of the Capital, abstained from the performance of surgical operations. There is something extremely interesting in observing how very similar our notions and actions in this respect are with those entertained and practised sixteen hundred years ago.

In regard to Galen it may be said, as was truly affirmed of Hippocrates, that his amazing superiority to his contemporaries for a very long period repressed any attempts at further improvement in the science and art of medicine. The names of some of those who flourished at the same time as Galen have reached us; and the learned Le Clerc, and in some measure too the erudite Sprengel, deserve no small amount of credit for rescuing from oblivion those of not a few which would otherwise have perished. But in judging of the merits of men-and this is perhaps truer of our profession than of any other, though true of all-we are too apt to consider those only who have been great authors, while unfortunately it has not unfrequently happened, and happens still, that the man who has seen most, and is best able to write because he has most to write about, is summoned hence ere posterity are favoured, or even contemporaries have profited, to the extent they might have done; this is a point which should not be forgotten by the student of the History of Medicine.

With a brief notice of the Greek writers subsequent to Galen, and an interesting chapter on the Laws and Customs of the Roman Empire in Relation to the Medical Profession, the work of Dr. Watson is for the present brought to a close. From his preface we are led to expect a further contribution to the History of Medicine-this time among the Arabs and in the schools of the middle ages. We can only say that we shall be glad to welcome any additional fruits of his labours, feeling satisfied that these will be the result of a careful and reflective study; for though in the volume before us there is no distinct manifestation of a profound acquaintance with the ancient authors themselves, there is abundant evidence of Dr. Watson's familiarity with the writings of both ancients and moderns who have devoted attention to the History of Medicine.

In noticing a work of merit and excellence such as Dr. Watson's, it is a pleasing duty to conelude without a single word of adverse criticism, and we shall not deny ourselves that gratification; at the same time we take the liberty of counselling a more exact revision of his proofs by Dr. Watson in the event of a second edition being called for. The references to authors are oftentimes inaccurate: for example, at foot of page 13, "Plinii Historia Naturalis, lib. xxix., cap. vi.-viii." is cited; but in the 29 th book of Pliny there are only six chapters! the reference should be lib. xxix., cap. i. Again, at page 149, it is annoying to find Satyrus spelt Satyrius, and the well-known instructor of Galen at Corinth, Numesianus, appearing as Normiscianus; while worse than either, Polybus, the distinguished son-in-law of Hippocrates; is throughout the book styled Polybius ! and might thus be confounded with the eminent historian of that name.

Of the book of Renouard, and the manner in which Dr. Comegys; the translator, has executed his task, we have already expressed a very 
favourable opinion.* Had our space permitted it, we should have been glad to have entered upon a fuller consideration of some of the more important doctrines which at various times were supported in the different schools of medicine, and to which in this article we have scarcely been able to do more than to allude. As regards these, the most suitable place for their discussion is no doubt the lecture-room; and we hope before long to find that in every important school of medicine in this country, opportunities will be afforded to students, whereby they may be enabled to attain some knowledge, at least, of the history of that profession to the practice of which their lives are to be devoted.

\section{REVIEW VII.}

Clinical Lectures on Certain Diseases of the Urinary Organs : and on Dropsies. By Robert Bentley Tod, M.D., F.R.S., Physician to King's College Hospital.-London, 1857. Small 8vo, pp. 435.

Is our day much is done, laudably done, and well done, by aspirants. The goddess who presides over medical affairs in London will not be approached by any who bring not in their hand some votive offering, as a testimony of their ability and diligence. It may be a heart, a lung, or a kidney, nor will she disdain an uterus, liver, or stomach. Something her worshippers must do to attract her regard, and obtain at least permission to be distinguished from the ignobile vulgus. And for their future it is much the same. The same efforts, the same offerings, are needful to obtain her further and higher favours as were required for the first. 'E $\rho \gamma \alpha$ ' $\zeta \varepsilon \sigma \theta \varepsilon$ is her response to all the petitions that daily beset her. And of a verity the oracle is obeyed, and on all sides work is done, and by very many right good work, that bears well-deserved golden fruit. But apart from these, though once of them, are a few, the elect (not those of the College of Physicians), who are accepted and privileged. To them the gates of the golden shrine are open, they enter when they will, and on them the goddess sheds her choicest favours. They have attained above the region of strife and contest, and walk (or rather drive) in calm and secure dignity!

- Perfecto munere Divæ-

Devenere locos lætos, et amœna vireta

Fortunatorum nemorum, sedesque beatas."

Now, to the praise of some of these, it is to be said that they still pursue their labours, though for their own sakes unneeded. They use their advantages, and improve them, more for the good of others than their own. Their work is from the purest motive, and can scarcely fail to be of the highest order.

Among these distinguished worthies, Dr. Todd holds his place most deservedly. He has steadily laboured for the promotion of rational medicine, not only by his personal exertions, but by calling forth and

* Dr. Comegys also has allowed many errors of the press to escape his notice. At p. 39 there is a very stupid one. Cleyer specimen Medica Sinice, should be Cleyer specimen Medicinæ Sinicæ; and at p. 42, the author's name Cleyer appears as Fleyer. Many others might be noticed. 